Role of agricultural engineering in environmental and sustainable development for the valley and delta areas: 1890 -1906

\title{
VISIBLE LASER BEAM FOR QUALITY EVALUATION OF COW MEAT
}

\author{
H. E. Hassan ${ }^{1}$, A. A. Abd El-Rahman ${ }^{2}$ and F. M. Shehata ${ }^{3}$
}

\begin{abstract}
The aim of this research work was to determine the physical and chemical properties of different muscles cuts of cow meat, studying the relationship among optical properties, physical and chemical properties of meat samples and quality evaluation for cow meat. The research work was carried out at Institute of Laser Enhanced Science (NILES), Cairo University, Giza, Egypt. Four the samples muscles cuts were named Round, Shoulder, Hind shank and Best ribs. Determination of chemical and physical characteristics of the meat samples, and optical properties (reflection and absorption) were measured during 2009.

The obtained results were as following: (1) The reflection intensity was decreased and the absorption intensity was increased of meat cut types of cow, resulted to increase of water holding capacity, cooking loss and shear force for best ribs, shoulder, round and hind shank, respectively., (2) By increasing the moisture content and fat percentages of meat samples surface, led to increase the reflection percentage of sample. So, the best ribs of meat sample more reflection than, shoulder and round. While, the hind shank of meat sample was the less of reflection percent., (3) By increasing the moisture content and fat percentages of meat samples surface, led to decrease the absorption percentage of sample. So, the best ribs of meat sample high reflection (66.528 Lux) and less absorption (883.471 Lux) than, shoulder and round. While, the hind shank of meat sample was the more of absorption (914.885 Lux) and less reflection (35.114 Lux), and (4) Laser technique can be used for quality evaluation of meat caw with accuracy and easily.
\end{abstract}

1- Associate Prof., Nat. Inst. of Laser Enhanced Sc. (NILES), Cairo Univ., Egypt.

2- Senior Researcher, Agric. Eng. Res. Institute, Agric. Res. Center, Dokki, Egypt. 3- Student of Postgraduate, Nat. Inst. of Laser Enhanced Sc. (NILES), Cairo Univ., Egypt.

The $17^{\text {th }}$. Annual Conference of the Misr Society of Ag. Eng., 28 October, $2010 \quad-1890-$ 


\section{INTRODUCTION}

Meat is the most delicious, nutritious flavorful and palatable of all food. It constitutes a valuable part of human diet because of its high content of protein and other nutrients e.g. fats, minerals and desirable food (Lawrie1998).

Du and Sun (2005) reported that a world has been looking for development in technology. LASER is one of these technologies, and there are many applications at several fields such as agriculture, communication and medicine.

Downey (1996) said that one of the advantages of Near Infrared Reflectance Spectroscopy (NIRS) technology is not only to assess chemical structures through the analysis of the molecular bonds in the near infrared spectrum, but also to build a characteristic spectrum that represents the "finger print" of the sample.

Hildrum et al. (1995) mentioned that the near infrared spectroscopy (NIRS) has been also used in qualitative analysis as a discriminate tool serving to the identification and authentication of foods. Also, it is a sensitive, fast and non-destructive analytical technique with simplicity in sample preparation.

Shenk and Westerhaus (1996) found that a strong relationship between spectra and chemical composition, which represents good quantitative information of the spectra change according to chemical composition and that with an appropriate data management the chemical features, can be elucidated. Particularly for dry matter, in both extremes (below 23 and above 26\%) of the moisture range and for ether extract, especially in the highest range (above 4\%) of fat content.

Hatem and Shatadal (1999) referred to the Near-infrared (NIR) spectral features have also been studied for beef tenderness prediction. Short loins were removed for sensory tenderness evaluation by a trained panel as described previously and for NIR imaging.

Downey et al. (2000) said that the near Infrared Reflectance Spectroscopy (NIRS) can determine the quality of the muscle. The use 
of (NIRS) to discriminate between kangaroo and beef meat and chicken meat cuts, lamb and beef mixtures and between beef, pork, chicken and pork. Most of the spectral information used for the discrimination analysis is contained in the visible region (400-700 nm) and in the (NIR) region around (1400-2300 $\mathrm{nm}$ ) due to both different pigments present in each specie and to matrix characteristics (intra-muscular fat, fatty acids, moisture).

Swatland (2002) said that the relationship between paleness and refraction. When light is refracted as it passes through meat. The original directionality of the light may be maintained farther if refraction is weak, allowing incident light to pass deep into the meat where it is absorbed. But, when refraction is strong, the original directionality may soon be lost, more light is returned to the meat surface, and it appears pale.

Alomar et al. (2003) found that the near infrared spectroscopy (NIRS) can be used as a helpful tool for identifying breed and muscle type in beef meat, on an objective, composition-related basis and to achieve fast predictions of meat composition with reasonable accuracy, particularly for protein and fat content.

Cozzolinoa and Murray (2004) suggested that the visible (VIS) and near infrared reflectance spectroscopy (NIRS) was used to identify and authenticate different meat muscle species. Samples from beef (n: 100), lamb (n: 140), pork (n: 44) and chicken (n: 48) muscles were homogenized and scanned in the visible (VIS) and near infrared (NIR) region (400-2500 nm) in a monochromatic instrument in reflectance.

Arthur et al. (2005) cleared that the low-dose, low-penetration electron beam (E-beam) irradiation has great potential as an antimicrobial intervention in the beef slaughter process. Because contamination of beef carcasses by pathogenic bacteria occurs on the external surface, a broadspectrum antimicrobial intervention that produces large reductions in pathogen load while minimally affecting the carcass would be ideal.

Zheng (2006) referred to an image features from near-infrared (NIR) imaging, which can be adopted to capture images at different wavelength and modalities. Using microscopy, fiber structure of beef can be captured 
in images from which it is believed that tenderness can be better evaluated. With magnetic resonance imaging (MRI) and ultrasonic imaging (UI), the internal structure of beef joints can be nondestructively revealed for indicating the chemical properties.

Schlutz and Derickson (2007) suggested that There are several factors related to tenderness that can be touched on with the reflect-meter technique. The most promising factors in terms of determining the tenderness meat are connective tissue and protein densities.

Prieto et al. (2008) said that the near infrared spectroscopy (NIRS) could discriminate in all cases ground beef samples from different animals protected by the same quality mark. The success of the process seems to be related to the differences in intramuscular fat and water contents, which could be detected by (NIRS) spectra.

The objectives of this research work were to determine of physical and chemical properties for different muscles cuts of cow meat, studying the relationship among optical properties and physical and chemical properties of meat samples and quality evaluation for cow meat.

\section{MATERIAL AND METHODS}

The present research is studying laser techniques for quality evaluation of cow meat. The optical properties were carried out at the Laboratory of Laser Application in Agricultural Engineering at National Institute of Laser Enhanced Science (NILES), Cairo University, Egypt and the physical and chemical properties of meat samples were analyzed in the Research Park, Faculty of Agriculture, Cairo University, Giza, Egypt during 2009.

\section{1-Animal and meat samples:}

Meat samples were obtained from the researching farm of the Faculty of Agriculture, Cairo University, Egypt. It was taken from carcass of male of Egyptian native cattle (Baladi Bullocks), healthy and free from diseases. With a live weight of $350 \mathrm{~kg}$ at an average age of two years. It was fed with green fodder.

The animal slaughter and dressing followed normal commercial procedures. The samples, were abscised from four muscles representing 
common retail cuts in the local market in Egypt :( Round (Leg), Shoulder, Hind shank and Best ribs). As shown in Fig. (1) the beef samples were sectioned into smaller slices', and divided into shares with weight (approximately $150-200 \mathrm{~g}$ ). The beef samples were kept in a fridge $\left(4 \pm 8^{\circ} \mathrm{C}\right)$ for 24 Hours in plastic bags before carrying out the measurements.

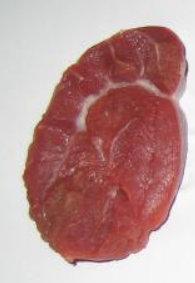

Hind Shank

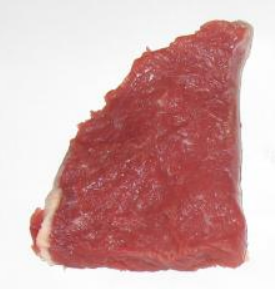

Shoulder

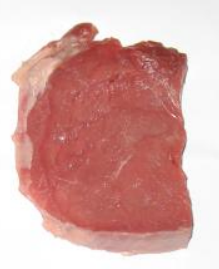

Leg

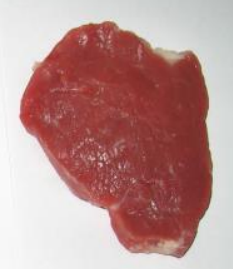

Best Ribs

Fig. (1): The meat samples, representing common retail cuts in the local market in Egypt.

2- Chemical analysis: to determine of the meat samples such as moisture, protein, fat and collagen, using Food Scan Pro meat analyzer (Foss Analytical A/S, Model 78810, and Denmark). According to the manufacturer's instructions about 50 - $100 \mathrm{~g}$ of raw meat samples' were minced and put in the meat analyzer cup. The cup was inserted into the meat analyzer for scanning sample with infra red to determine the chemical components.

The ash content was determined by weighted 10 gm of muscle samples into porcelain crucible previously weighted. Samples were heated at 100 ${ }^{\circ} \mathrm{C}$ to expel moisture, and then were placed in temperature controlled to $600{ }^{\circ} \mathrm{C}$, and hold at this temperature for 2 hours. The ash percentage was calculated by the following equation.

Ash \% $=(\mathrm{W} 1-\mathrm{W} 2) / \mathrm{W} 1 \times 100$

Where: $\mathrm{W} 1=$ sample weight before measuring, $\mathrm{g}$ and

$\mathrm{W} 2=$ sample weight after measuring, $\mathrm{g}$ 
PROCESS ENGINEERING

\section{3-Physical characteristics:}

Physical characteristics such as cooking loss, water holding capacity, shear force, $\mathrm{pH}$, and color were measured.

Water Holding Capacity (\%), was measured which meat sample of about $0.3 \mathrm{~g}$ (W3) was placed on a filter paper and then subjected to a pressure of $1000 \mathrm{~g}$ for 10 minutes. The expressible fluid was estimated in the following equation.

Water Holding Capacity \% = (W3-W4)/W3x100

Where: W3= sample weight before measuring, $g$ and

$\mathrm{W} 4=$ sample weight after measuring, $\mathrm{g}$

Cooking loss (\%), was determined using 2 cubes of meat (about $100 \mathrm{gm}$, W5). The samples were boiled in saline $(0.09 \% \mathrm{Nacl})$ for 45 minutes, and then were left to be cool at room temperature. Sample was reweighed (W6) to calculate the cooking loss percentage according to the following equation.

Cooking loss, $(\%)=($ W5-W6 $) / W 5 \times 100$

Where: W5= sample weight before measuring, $g$ and

W6= sample weight after measuring, $g$

Shear force $(\mathbf{N})$, the cooked samples were used for determining the shear force $(\mathrm{N})$. For estimating shear force using Instron Universal Testing Machine (Model 2519-105, USA). The shear force machine was adjusted at crosshead speed of $200 \mathrm{~mm} / \mathrm{min}$.

pH, was measured using five grams of meat according to the following methodology. Samples were minced, and put in graduated glass beaker, before filling the beaker with distilled water up to $50 \mathrm{ml}$. The mixture (meat and water) was shacked. $\mathrm{PH}$ of the obtained suspension was measured by Micro processor $\mathrm{pH}$ meter ( $\mathrm{PH} 211$, Micro processor $\mathrm{pH}$ meter, Hanna instruments, Italy).

\section{4- Optical properties:}

The optical properties such as reflection and absorption intensities of the meat samples were done at the Laboratory of Laser Application in Agricultural Engineering at National Institute of Laser Enhanced Science (NILES), Cairo University, Egypt.

The Samples were scanned. Spectra were taken by reflectance in a Helium-neon (He- Ne) $632.8 \mathrm{~nm}$ laser beam. 


\section{Setup for laser technique:}

The experimental setup was developed and assembled in the Laboratory of Laser Application in NILES, Cairo University, Egypt. It consists of laser source, lens, holders, and digital luxmeter as shown in Fig. (2).
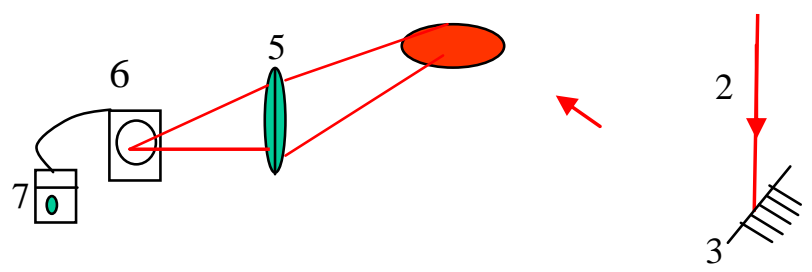

(a): Schematic diagram.

1- Laser source, 2- Laser beam, 3- Mirror, 4- Meat sample,

5- Convex lens, 6- Detector and 7- Luxmeter.

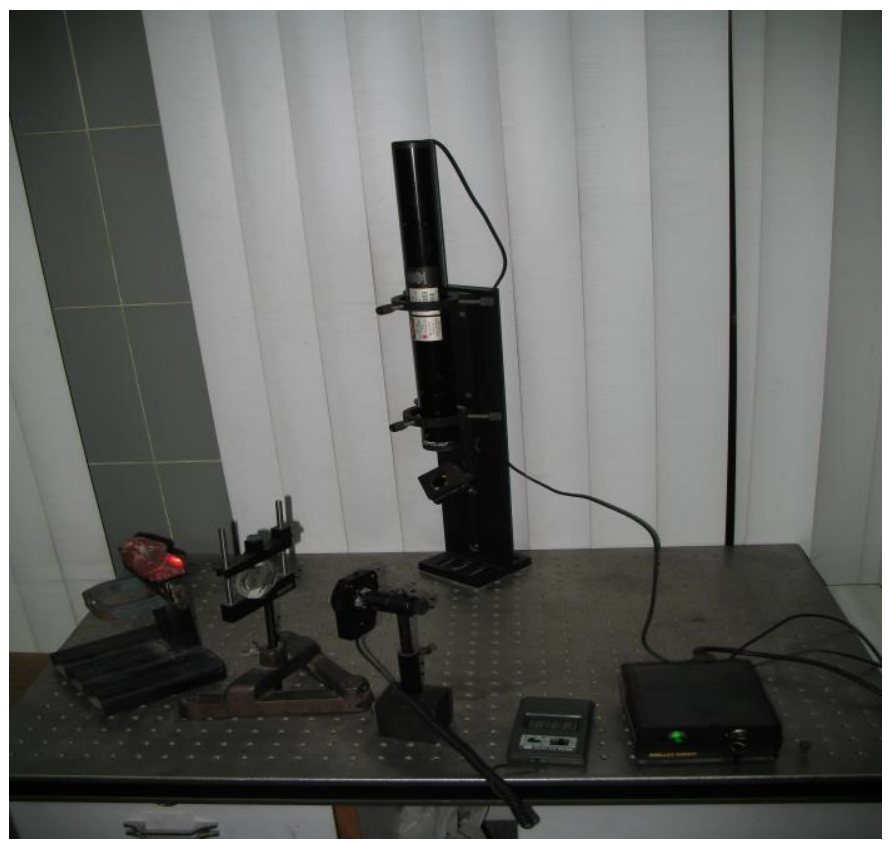

(b): Experimental setup.

Fig. (2): Setup for measuring optical proprieties of meat samples. 


\section{RESULTS AND DISCUSSION}

The obtained results were presented and discussed, to determine the optical properties of different muscle cut types of cow meat and to evaluate quality for cow meat using visible laser.

Table (1) and Fig. (3) indicated that the relationship between optical properties such as the reflection intensity and physical properties such as the shear force, cooking loss, and water holding capacity percentage of meat cut types of cow. It showed that the values of reflection were decreased from 66.528, 54.371, 45.8 and 35.114 Lux for best ribs, shoulder, round and hind shank, respectively. This reduction of reflection percentage related with the water holding capacity percentage was increased from $26.18,29.07,31.43$ and $37.7 \%$, and the shear force was increased from 4.82, 5.26, 6.25 and 9.31, N. while the cooking loss was decreased from $51.88,49.65,46.44$ and $43.66 \%$ for best ribs, shoulder, round and hind shank, respectively.

Table (1): Effect of chemical and physical characterizations on optical properties of meat cut types of cow.

\begin{tabular}{|c|c|c|c|c|c|c|}
\hline \multirow[b]{2}{*}{$\begin{array}{l}\text { Meat cut } \\
\text { types }\end{array}$} & \multicolumn{6}{|c|}{ Chemical properties for meat cut types of cow } \\
\hline & $\begin{array}{c}\text { Ash, } \\
\%\end{array}$ & Collagen, & Fat, & $\begin{array}{c}\text { Protein, } \\
\%\end{array}$ & $\mathrm{PH}$ & $\begin{array}{c}\text { Moisture } \\
\text { content,\% }\end{array}$ \\
\hline Best Ribs & 1.28 & 0.93 & 1.67 & 20.34 & 5.5 & 75.75 \\
\hline Shoulder & 1.25 & 1.39 & 1.55 & 21.25 & 5.59 & 75.35 \\
\hline Round & 1.19 & 1.52 & 1.33 & 21.48 & 5.65 & 74.93 \\
\hline \multirow[t]{3}{*}{ Hind shank } & 1.06 & 1.77 & 0.82 & 21.75 & 6.02 & 74.55 \\
\hline & \multicolumn{6}{|c|}{ Physical properties for meat cut types of cow } \\
\hline & \multicolumn{2}{|c|}{ Shear force, N. } & \multicolumn{2}{|c|}{$\begin{array}{l}\text { Cooking } \\
\text { Loss, \% }\end{array}$} & \multicolumn{2}{|c|}{$\begin{array}{l}\text { Water holding } \\
\text { capacity, } \%\end{array}$} \\
\hline Best Ribs & \multicolumn{2}{|c|}{4.82} & \multicolumn{2}{|c|}{51.88} & \multicolumn{2}{|c|}{26.18} \\
\hline Shoulder & \multicolumn{2}{|c|}{5.26} & \multicolumn{2}{|c|}{49.65} & \multicolumn{2}{|c|}{29.07} \\
\hline Round & & 6.25 & \multicolumn{2}{|c|}{46.44} & \multicolumn{2}{|c|}{31.43} \\
\hline \multirow[t]{3}{*}{ Hind shank } & & 9.31 & 43 & & & 7.7 \\
\hline & \multicolumn{6}{|c|}{ Optical properties for meat cut types of cow } \\
\hline & \multicolumn{3}{|c|}{ Reflection, Lux } & \multicolumn{3}{|c|}{ Absorption, Lux } \\
\hline Best Ribs & \multicolumn{3}{|c|}{66.528} & \multicolumn{3}{|c|}{883.471} \\
\hline Shoulder & \multicolumn{3}{|c|}{54.371} & \multicolumn{3}{|c|}{895.628} \\
\hline Round & \multicolumn{3}{|c|}{45.823} & \multicolumn{3}{|c|}{904.211} \\
\hline Hind shank & \multicolumn{3}{|c|}{35.114} & \multicolumn{3}{|c|}{914.885} \\
\hline
\end{tabular}



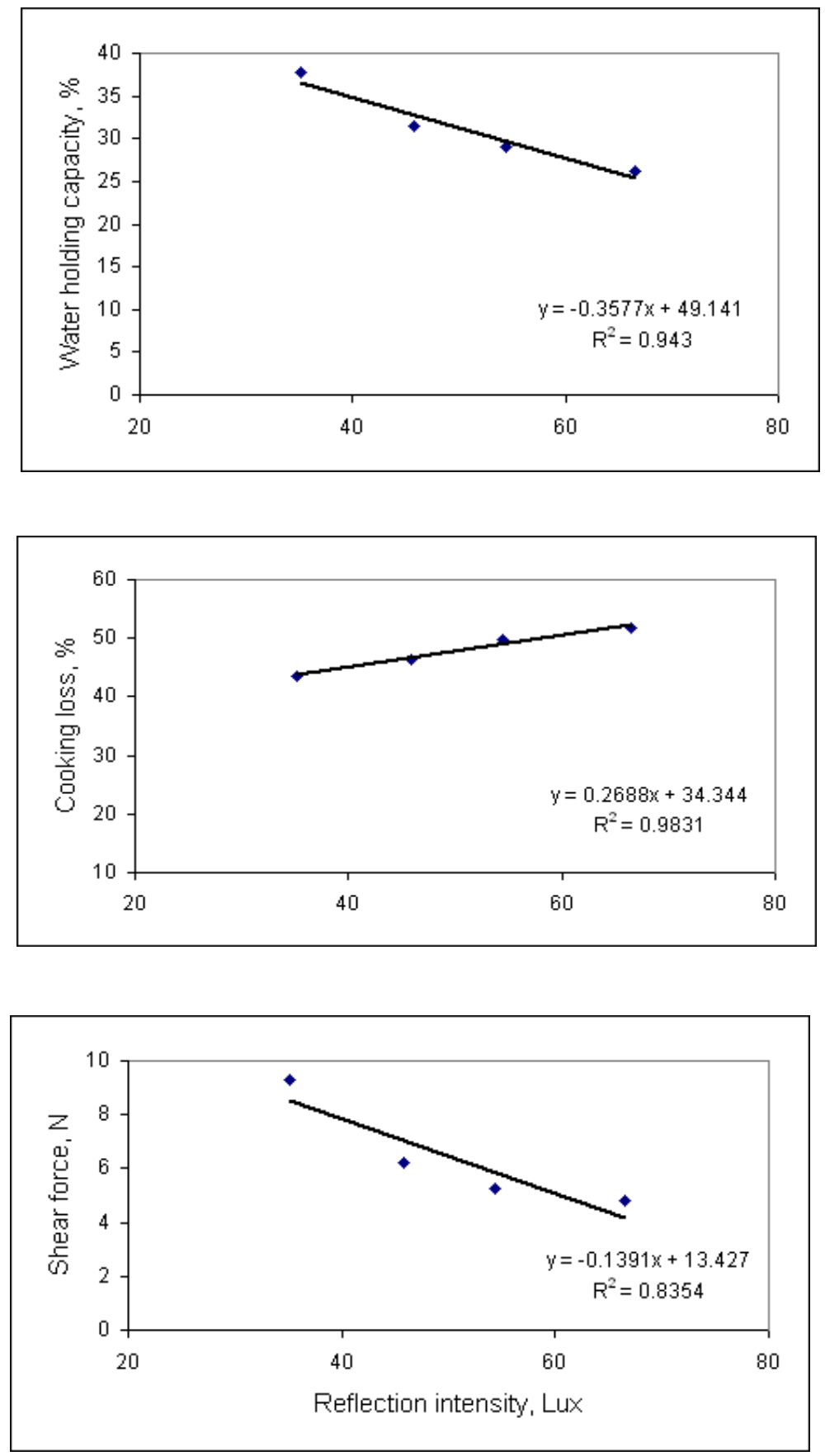

Fig.(3): Relationship among reflection intensity (x) and shear force, cooking loss and water holding capacity of meat cut types of cow. 
Fig (4) shows the relationship between optical properties such as the absorption intensity and physical properties such as shear force, cooking loss, and water holding capacity percentage of meat cut types of cow. It noticed that the absorption intensity values were increased from 883.471, 895.628, 904.211 and 914.885 Lux., for best ribs, shoulder, round and hind shank. This increases related with increasing the water holding capacity percentage from 26.18, 29.07, 31.43 and $37.7 \%$ and the shear force from 4.82, 5.26, 6.25 and 9.31, N. while, the cooking loss was decreased from 51.88, 49.65, 46.44 and $43.66 \%$ and for best ribs, shoulder, round and hind shank, respectively.

Therefore, the reflection intensity was decreased and the absorption intensity was increased of meat cut types of cow, resulted to increases of water holding capacity, cooking loss and shear force for best ribs, shoulder, round and hind shank, respectively.

Fig. (5) shows the relationship between optical properties such as the reflection intensity and chemical properties such as moisture content, protein, fat, collagen, and ash percentage and $\mathrm{PH}$ values of meat cut types of cow. By decreasing the moisture content percentage from 75.75, $75.35,74.93$, and $74.55 \%$, fat percentage was decreased from $1.67,1.55$, 1.33 and $0.82 \%$, and ash percentage was decreased from 1.28, 1.25, 1.19 , and $1.06 \%$ while the protein percentage was increased from 20.34, $21.25,21.48$, and $21.75 \%$, the $\mathrm{pH}$ values was increased from 5.5, 5.59, 5.65 and 6.02 and collagen percentage was increased from 0.93. 1.39, 1.52 , and $1.77 \%$, the values of reflection were decreased from 66.528, 54.371, 45.8 and 35.114Lux for best ribs, shoulder, round and hind shank, respectively. That is mean by increasing the moisture content and fat percentages of meat samples surface led to increase the reflection percentage of sample. So, the best ribs of meat sample more reflection than, shoulder and round. While, the hind shank of meat sample was the less of reflection percent. 

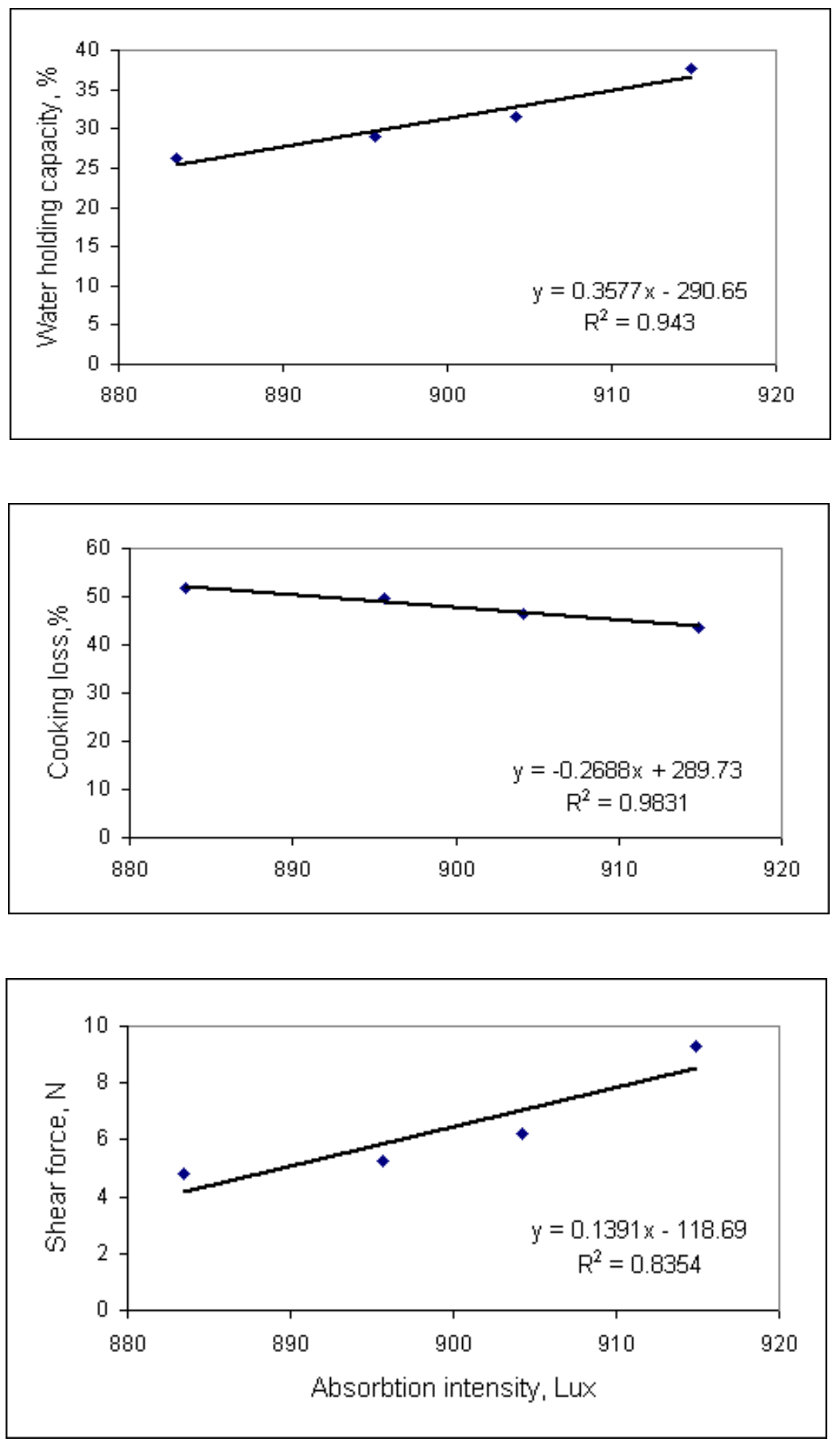

Fig.(4): Relationship among absorption intensity (x) and shear force, cooking loss and water holding capacity of meat cut types of cow. 

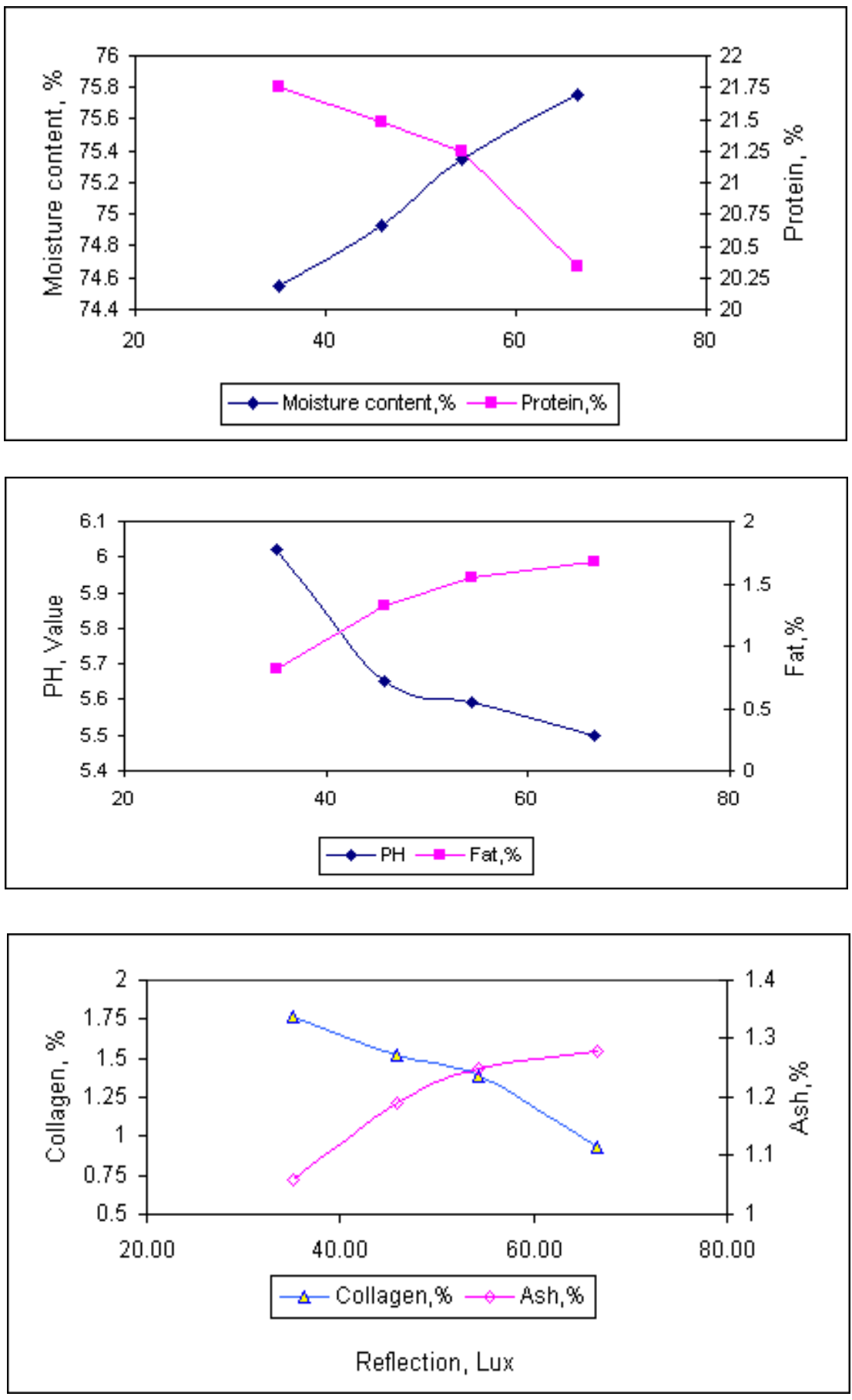

Fig.(5): Relationship among reflection intensity and moisture content, protein, fat, collagen, ash and $\mathrm{pH}$ values of meat cut types of cow. 


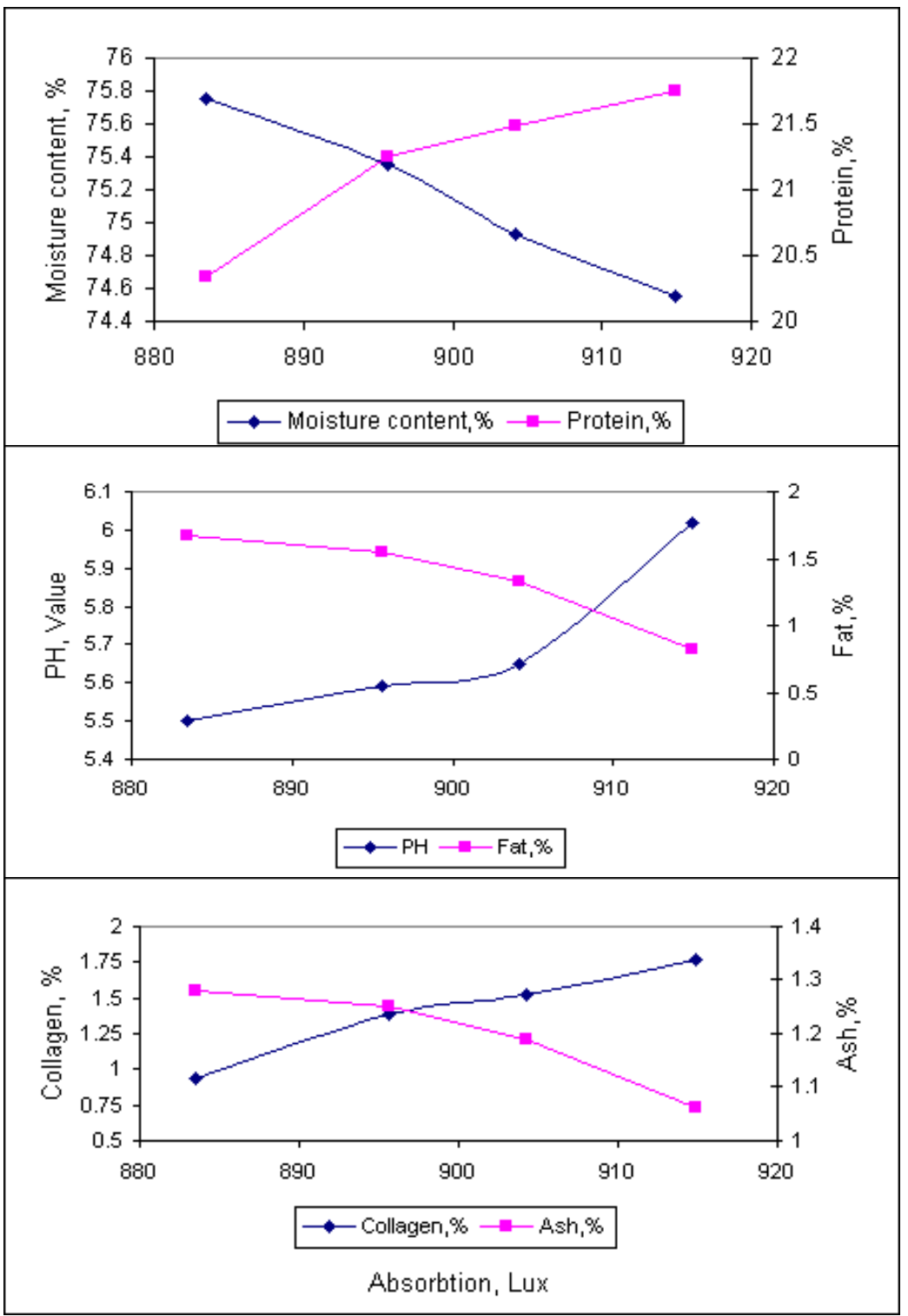

Fig (6): Relationship between absorption intensity and moisture content, protein, fat, collagen, and ash and $\mathrm{pH}$ values of meat cut types of cow. 
Fig (6) shows the relationship between optical properties such as the absorption intensity and chemical properties such as moisture content, protein, fat, collagen, and ash percentage and $\mathrm{pH}$ values of meat cut types of cow. It cleared that when the absorption intensity values were increased from 883.471, 895.628, 904.211 and 914.885 Lux for best ribs, shoulder, round and hind shank. This increases related to the decrease in moisture content percentage from $75.75,75.35,74.93$, and $74.55 \%$, fat percentage from $1.67,1.55,1.33$ and $0.82 \%$, and ash percentage was decreased from $1.28,1.25,1.19$, and $1.06 \%$ while increases the protein percentage from $20.34,21.25,21.48$ and $21.75 \%$, the $\mathrm{pH}$ values from 5.5, 5.59, 5.65, and 6.02 value and collagen percentage from $0.93,1.39$, 1.52 , and $1.77 \%$, and for best ribs, shoulder, round and hind shank, respectively. That is mean by increasing the moisture content and fat percentages of meat samples surface, led to decrease the absorption percentage of sample. So, the best ribs of meat sample less absorption than, shoulder and round. While, the hind shank of meat sample was the more of absorption percent.

\section{CONCLUSION}

The obtained results were as follows: (1) The reflection intensity was decreased and the absorption intensity was increased of meat cut types of cow, resulted to increases of water holding capacity, cooking loss and shear force for best ribs, shoulder, round and hind shank, respectively., (2) By increasing the moisture content and fat percentages of meat samples surface, led to increase the reflection percentage of sample. So, the best ribs of meat sample more reflection than, shoulder and round. While, the hind shank of meat sample was the less of reflection percent. (3) By increasing the moisture content and fat percentages of meat samples surface, led to decrease the absorption percentage of sample. So, the best ribs of meat sample high reflection (66.528 Lux) and less absorption (883.471 Lux) than, shoulder and round. While, the hind shank of meat sample was the more of absorption (914.885 Lux) and less reflection (35.114 Lux), and (4) Laser technique can be used for quality evaluation of meat caw with accuracy and easily. 
PROCESS ENGINEERING

\section{REFERENCES}

Alomar, D.; C. Gallo; M. Castaneda, and R. Fuchslocher (2003). Chemical and discriminate analysis of bovine meat by Near Infrared Reflectance spectroscopy (NIRS). Meat Science, 63: 441450.

Arthur, T. M.; T. L. Wheeler; S.D. Shackelford; J. M. Bosilevac; X. Nou, and M. Koohmaraie (2005). Effects of Low-Dose, LowPenetration Electron Beam Irradiation of Chilled Beef Carcass Surface Cuts on Escherichia coli O157:H7 and Meat Quality. Journal of Food Protection. 68 (4) : 666-672.

Cozzolinoa, D. and I. Murray (2004). Identification of animal meat muscles by visible and near infrared reflectance spectroscopy. Swiss Society of Food Science and Technology, 37:447-452.

Downey, G. (1996). Authentication of food and food ingredients by near infrared spectroscopy. J.Near Infrared Spectroscopy, 4, 47-61.

Downey, G.; J. McElhinney and T. Fearn (2000). Species identification in selected raw homogenized meats. By reflectance spectroscopy in the mid-infrared, near-infrared and Visible ranges. Applied Spectroscopy, 54:894-899.

Du, C. J. and D.W. Sun (2005). Correlating shrinkage with yield, water content and texture of Pork ham by computer vision. Journal of Food Process Engineering, 28: 219-232.

Hatem, I.; J. Tan; and P. Shatadal (1999). Beef quality prediction by using near-infrared image features. ASAE Annual International Meeting, Paper no. 993159. Pages:1-10.

Hildrum, K. I. ; T. Isaksson; T. Naes; T. Nilsen; B. N.; M. Rodbotten and P. Lea (1995). Near Infrared reflectance spectroscopy in the prediction of sensory Properties of beef. Journal of Near Infrared Spectroscopy, 3: 81-87.

Lawrie, R. A. (1998). Lawrie's Meat Science. Wood head Publishing Limited, Cambridge, UK. Pp: 45 and 98.

Prieto, N.; S. Andre's; F. J. Gira'ldez; A.R. Manteco'n; P. Lavı'n (2008). Discrimination of adult steers (oxen) and young cattle 
ground meat Samples by near infrared reflectance spectroscopy (NIRS). Meat Science, 79:198-201.

Schlutz, M. and D. Derickson (2007). Optical Low Coherence Reflectometry Applications to Meat Tenderness Testing Honors Research Project California Polytechnic State University, San Luis Obispo Pp.:1-11.

Shenk, J.; M. Westerhaus (1996). Near infrared spectroscopy: the future waves Chichester: NIR Publications. Pp.: 198-202.

Swatland, H. G. (2002). Refractometry of pork muscle and beef connective and adipose tissue .Meat Science, 62:225-228.

Zheng, C. (2006). Development of novel image segmentation and image feature extraction techniques and their applications for the evaluation of shrinkage moisture content, and texture of large cooked and cooled beef joints. Agriculture and Veterinary Medicine University College Dublin. National University of Ireland Pp.:158-171.

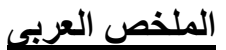

\section{شعاع الليزر المرئى لتقييم جودة اللحم}

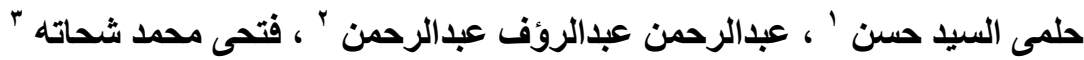
تهدف هذه الدر اسة الى استخدام شعاع الليزر لتحديد بعض العو امل المحددة لجودة اللحم البقرى



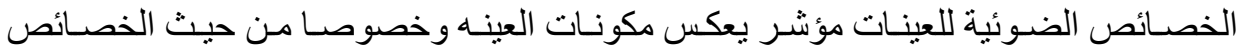

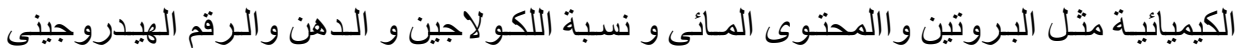

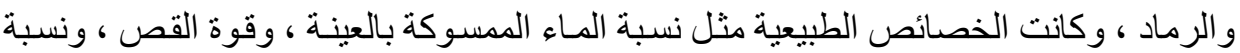

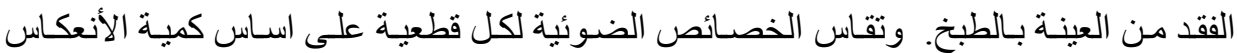

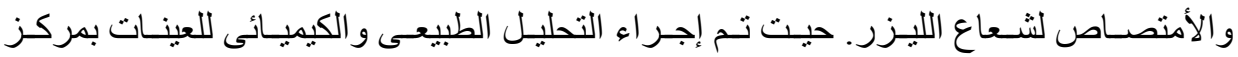

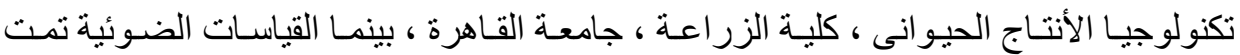

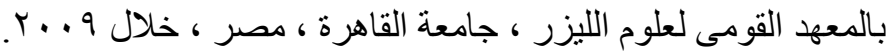

1ـ أستاذ مساعد تطبيقات الليزر فى الهندسة الزراعة ـ المعهد القومى لعلوم الليـزر - جامعـة القاهرة ـ مصر.

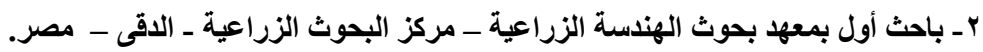

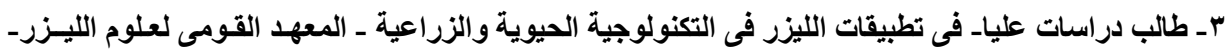

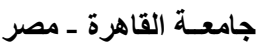




\section{أوضحت النتائج المتحصل عليها الأتى :}

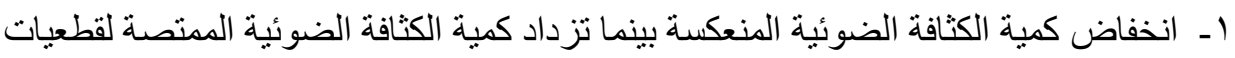

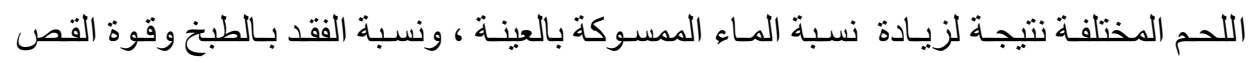

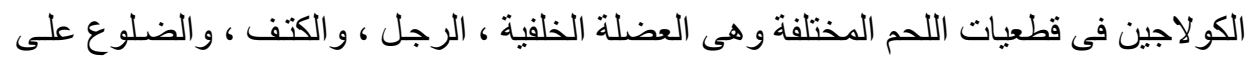

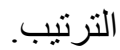

r-بالنسبة للخصائص الكيميائية لقطعيات اللحم المختلفة ، أتضح زيادة كل من المحتوى المـائى ،

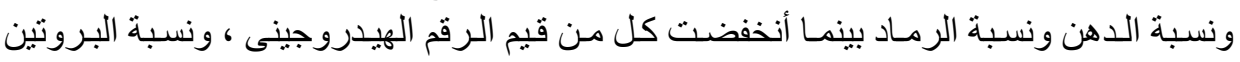

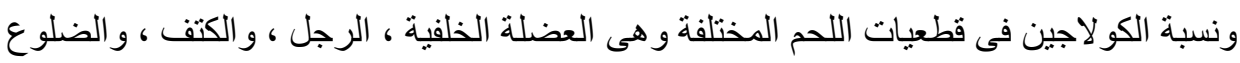

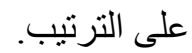
rا-بالنسبة للخصائص الطبيعية لقطعيات اللحم المختلفة ، أتضح أنخفاض كل من المحتوى المائى

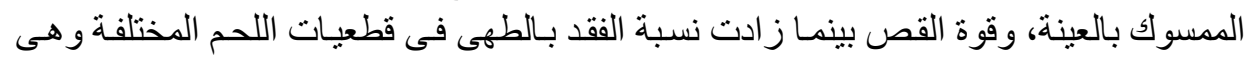

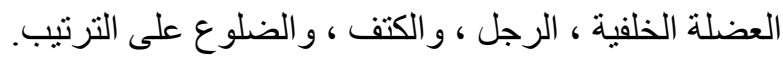

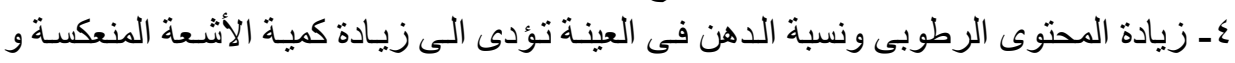

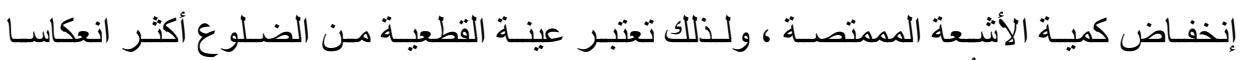
،

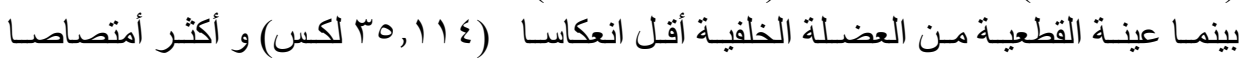
. ○ـ يمكن أستخدام تقنية الليزر للتعرف و التمييز بين أنواع قطعيات اللحم بدقة وسهولة. 